\title{
Fabrication of Graphene Oxide-MWCNTs Nanocomposite Modified Glassy Carbon Electrode for the Sensitive Determination of Amitrole
}

\author{
Rajkumar Devasenathipathy ${ }^{*}$ Karuppasamy Kohila rani, Sea-Fue Wang ${ }^{*}$ \\ Department of Materials and Mineral Resources Engineering, No. 1, Sec. 3, Chung-Hsiao East Rd., \\ National Taipei University of Technology, Taipei, Taiwan \\ *E-mail: chemrackz@gmail.com, sfwang@ntut.edu.tw
}

doi: $10.20964 / 2017.07 .86$

Received: 13 April 2017 / Accepted: 19 May 2017 / Published: 12 June 2017

We have demonstrated a highly sensitive amperometric amitrole (3-Amino-1,2,4-triazole) sensor constructed with graphene oxide (GO) and multi walled carbon nanotubes (MWCNTs) through electrochemical potentiostatic approach. The characterization studies of GO-MWCNTs composite were performed using field emission scanning electron microscopy (FESEM), cyclic voltammetry (CV) and amperometric i-t techniques. The high performance of GO-MWCNTs modified electrode towards amitrole was confirmed from the resulting low over potential and well defined sharp peak currents. The high sensitivity $\left(4300 \mu \mathrm{A} / \mathrm{mM} \mathrm{cm}^{-2}\right)$ and low limit of detection $(0.450 \mu \mathrm{M})$ were attained by our fabricated electrode in a wide working potential range from 5 to $3545 \mu \mathrm{M}$ (linear range). GOMWCNTs film coated glassy carbon electrode (GCE) also offers considerable stability along with good repeatability and reproducibility. The demonstration of practicability for our fabricated modified electrode was achieved in lake and tap water samples.

Keywords: Graphene oxide, MWCNTs, cyclic voltammetry, amperometry, Amitrole.

\section{$\underline{\text { FULL TEXT }}$}

(C) 2017 The Authors. Published by ESG (www.electrochemsci.org). This article is an open access article distributed under the terms and conditions of the Creative Commons Attribution license (http://creativecommons.org/licenses/by/4.0/). 